\title{
Study of the diversity and mapping of xerophytic vegetation of the southeastern coast of Crimea peninsula using remote sensing data
}

\author{
Nikolai B. Ermakov ${ }^{1,2,3}$, Igor A. Pestunov ${ }^{1,4}$, Vladislav V. Korzhenevskiy ${ }^{1}$, \\ Elena V. Ermakova ${ }^{1}$, Sergey A. Rylov ${ }^{1,4}$ and Natalia A. Trusheva ${ }^{5}$ \\ ${ }^{1}$ Nikita Botanical Gardens - National Scientific Center of the RAS, Yalta, Crimea, Russia \\ ${ }^{2}$ Central Siberian Botanical Garden SB RAS, Novosibirsk, Russia \\ ${ }^{3}$ Khakassia State University, Abakan, Khakassia Republic, Russia \\ ${ }^{4}$ Federal Research Center for Information and Computational Technologies, Novosibirsk, Russia \\ ${ }^{5}$ Maykop State Technological University, Maykop, Adygeya Republic, Russia
}

\begin{abstract}
The study of diversity and ecological-phytocenotic mapping of the vegetation cover was carried out at the key area located in the eastern part of the Echki-Dag mountain range in the territory of the Lisya Bay Reserve (Eastern Crimea). A generalization of the classification and ecological patterns of vegetation was carried out to create a legend for a large-scale ecological-phytocenotic cartographic model (at the scale of 1:10000). The ecological-geomorphological series and combinations of xerophytic and mesoxerophytic plant communities indicating erosion-denudation processes on different substrates of the underlying parent rocks were the thematic basis of the cartographic model. The developed legend is based on the units of vegetation of the association rank obtained using the Braun - Blanquet method combined into ecological series in accordance with their position on the gradients of the leading ecological factors as well as on the hierarchy of phytochories determined by the categories of erosion-denudation relief of coastal slopes. The resulting vegetation map demonstrates the main regularities of the regional phyto-diversity and serves as the basis for assessing the resource potential of vegetation, its landscape-stabilizing and nature conservation value.
\end{abstract}

\section{Keywords}

Vegetation, geobotanical mapping, phytodiversity, ecology, plant resources, relief, Crimea.

\section{Introduction}

Large-scale mapping of vegetation is currently of great importance for the study of theoretical problems of phytodiversity, structure and dynamics of vegetation, as well as for solving applied problems of assessing natural resources and conservation of rare and endangered species. The mountain systems of the southeastern Crimea are characterized by a high diversity of zonal natural vegetation of the European-Siberian and Mediterranean types with a high level of floristic richness. Here, in a small area, ecologically diverse unique xerophytic plant communities form combinations due to the influence of regional geological-geomorphological, bioclimatic and floro-genetic processes. At the same time, this territory has been influenced by human activity

SDM-2021: All-Russian conference, August 24-27, 2021, Novosibirsk, Russia

$\bigoplus$ pestunov@ict.sbras.ru (I. A. Pestunov)

(c) (1) $\odot 2021$ Copyright for this paper by its authors. Use permitted under Creative Commons License Attribution 4.0 International (CC BY 4.0).

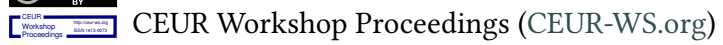


for a long time. It led to a decrease of natural vegetation and a wider spread of disturbed communities there. Therefore, large-scale geobotanical mapping forms the basis for regional assessing the degree of anthropogenic disturbance of vegetation and habitats, as well as the basis for assessing the conservation value of plant communities, monitoring the state of rare and endangered plant species. Until now, detailed large-scale mapping of vegetation cover as an indicator of ecological and anthropogenic changes in the natural environment of Crimea was carried out only for some geographically local areas. Maps of actual vegetation on the territory of the Republic of Crimea, made according to modern technological requirements using remote sensing data and modern computing technologies, are completely absent. There are only overview maps of potential vegetation, created on a small and medium scale [1,2], which can be very limitedly applied to solve modern large-scale economic and environmental problems.

At present, fundamentally new possibilities for correct and detailed representation of vegetation categories on geobotanical maps at different scales have appeared as a result of the development of GIS technologies and methods for processing remote sensing data. It has been implemented in various works [3, 4, 5]. N.B. Ermakov [6], M.A. Polyakova and N.B. Ermakov [7] studied the spatial patterns of steppe vegetation in the Minusinskaya intermountain basin using GIS technologies.

The aim of this study is to reveal the regularities of the spatial organization of natural vegetation in the mountain-steppe belt and to conduct a large-scale geobotanical mapping in a key area located on the territory of the Lisya Bukhta regional landscape reserve (the eastern part of the Echki-Dag mountain range) using remote sensing data.

\section{Materials and methods}

The study was carried out on the basis of 80 geobotanical releves of steppe vegetation carried out in accordance with the standard technique [8] on the plots of $100 \mathrm{~m} 2$. A whole series of releves was put into the database based on the European package TURBO (VEG) [9]. The methodology of the study was a system analysis that considers the vegetation cover as a complex hierarchically organized open mega-system with the leading role of ecological and geographical factors at different levels of its organization [10].

Vegetation classification was carried out using the Braun-Blanquet method [11]. The releves were quantitatively classified using cluster analysis implemented in the JUICE 7.0 program [12]. The nomenclature of syntaxonomic units was made in accordance with the Code of Phytosociological Nomenclature [13].

The assessment of the ecological peculiarities of the syntaxa habitats was carried out according to the results of the ecological analysis of floristic compositions using ecological species groups. These groups were distinguished by traditional methods $[14,15]$ by taking into account the attitude of plants to the following environmental factors: to the water regime of the habitat, to soil fertility, to the composition of bedrocks. The study of the vegetation spatial structure was performed in accordance with Sochava's approach [10] including the application of a classification system for phytocoenomeras and phytocoenochoras. The system of spatial categories of vegetation proposed by S.A. Gribova, T.I. Isachenko [16] was used as well. The regularities of 
the spatial organization of plant communities in connection with the dynamics of the relief on a cartographic model were studied on the basis of field interpretation of high-resolution satellite images (WorldView-2 with a resolution of $1.8 \mathrm{~m}$ ) using a multispectral image segmentation algorithm, based on computationally efficient hierarchical clustering algorithm HECA [17, 18], and spectral-texture segmentation algorithm ESEG [19]. These algorithms were developed within the framework of the grid-based and ensemble approaches and allow to extract hierarchically nested clusters of complex shapes, different sizes and densities, even in the case of intersecting clusters (in the space of spectral features). The processing of satellite information was carried out in the field so that the vegetation structures and individual plant communities revealed in the image could be found directly in the landscape. The boundaries of plant communities and phytochoras were identified as clearly as possible because this is very important for the organization of further long-term monitoring.

\section{Results and discussion}

A vegetation classification system was developed using the Braun-Blanquet approach. It includes 5 vegetation classes, 5 orders, 6 alliances and 15 associations. Such a high diversity of associations and higher categories in a relatively small area is explained by the diverse ecological conditions and the location of the study area to the plant-geographical border between the European and Mediterranean regions.

The spatial organization of the diversity of geographic and ecological categories of xerophytic vegetation is clearly determined by erosion-denudation slope processes in the eastern part of the Echki-Dag ridge on different types of bedrocks. Based on the analysis of the relations of plant communities with certain relief elements and the composition of ecological groups of species, it was revealed that the leading factor determining the formation of the highest spatial vegetation units is the geological-geomorphological process on the southern macro-slope of the mountain ridge. In accordance with this feature, the entire diversity of spatial units of vegetation is combined into two large altitude categories:

1) vegetation of the geomorphological belt of colluvial trails (200-400 m);

2) vegetation of the geomorphological belt of gully-ravine relief with a wide development of fluvial terraces $(0-150 \mathrm{~m})$.

Within each geomorphological belt, an assessment of the ecological regimes of certain habitats was carried out as a result of an analysis of the ratio of ecological groups of species indicating the leading factors of temperature, humidity, soil fertility and composition of bedrocks. The results of the analysis demonstrated the presence of a hierarchy of environmental factors, among which the petrographic composition of the bedrocks was the leading one, which contributes to the formation of large geomorphological belts in the eastern part of the Echki-Dag ridge. The factors of temperature and humidity determine the local regularities of certain vegetation types distributions on specific elements of relief within each geomorphological belt. Interpretation of WorldView-2 satellite images and recognition of vegetation categories directly in the field made it possible to reveal the basic ecological and topographic combinations of communities (series) and individual associations within each of the highest rank phytochories at a larger scale of mapping. 
The vegetation of the upper geomorphological belt of colluvial plumes at altitudes of 200-400 $\mathrm{m}$ is represented by four types of phytochories.

On weakly stony habitats of colluvial trails and in the upper parts of slopes, an ecological series of communities associated with a moisture factor has been identified. It is represented by associations of moderately drought-resistant communities Artemisio alpini-Festucetum callierii and the most xerophytic communities Artemisio tauricii-Koelerietum cristatii.

The vegetation of bedrock outcrops on the walls of the breakdown and drainage depressions of the erosion-landslide relief according to the results of interpretation of the satellite image is presented as a single phytochoria - a combination of a petrophytic series of associations that occupy habitats with poorly developed and fragmented soils - from communities of bedrock outcrops Euphorbio petrophyreti-Cotone communities of slopes with well-developed soil Artemisio tauricii-Koelerietum cristatii. The vegetation of bedrock outcrops on the walls of the breakdown and drainage depressions of the erosion-landslide relief according to the results of interpretation of the satellite image is presented as a single phytochoria - a combination of a petrophytic series of associations occupying habitats with poorly developed and fragmented soils - from communities of bedrock outcrops of Euphorbio petrophylli-Cotoneasteretum to weakly on trails of slopes with well-developed soil - Artemisio tauricii-Koelerietum cristatii.

Widespread erosional relief elements - landslides are ecologically homogeneous and occupied by an association of moderately petrophytic meso-xerophilous shrub communities of the CotinoPaliuretum. The most eroded habitats of the detachment walls of ancient landslides are occupied by petrophytic xerophytic communities of the association Onosmo rigidi-Asphodeletum tauricii.

A similar leading role of humidity and petrophytic factors is observed for the distribution of communities in the geomorphological belt of gully-gully relief with a wide development of fluvial terraces $(0-150 \mathrm{~m})$. Nevertheless, occupying lower hypsometric levels, this geomorphological belt is characterized by a generally flatter relief with a predominance of clay or loamy diluvium. Here, the most eroded slopes of ravines crossing the deposits of Maikop clays, fleeshes, sandstones and conglomerates create conditions for the mosaic distribution of smallsized communities of the xero-petrophytic ecological series: Ceratoido papposae-Seselietum dichotomii, Astrodauco orientali-Ptilostemonietum, Astragalo-Tragacantietum, which are closely related to the type of parent bedrocks and the corresponding moisture regimes.

The shaded parts of the ravine slopes are occupied by weakly petrophylous xero-mesophilous communities of juniper-oak forests and woodlands of the association funipero-Quercetum pubescentis.

A well-defined combination of low, moderately gentle proluvial terraces is characterized by relatively stable, slow erosion processes. A predominance of one xerophytic association Botriochloe-Paliurietum on well-developed soils is observed there.

Older wide high proluvial terraces are characterized by weakly pronounced erosion processes and are covered with a layer of loam, on which well-developed chernozem-type soils are formed. They are dominated by weakly petrophylous meso-xerophylous steppes the association Poteriofurinetum stoechadifolii. The higher ancient slopes with well-developed loamy soils resting on high proluvial terraces are occupied by xerophytic steppes of the association Medicago romanici-Bromopsietum cappadocii.

Ultra-xerophytic habitats widespread in the study area on steep eroded southern coastal slopes from Maikop clays and fleish (badlands) are occupied by the Mediterranean communities 


\section{of Atrophaco-Capparidetum.}

The regularities of the spatial organization of the diversity of plant communities in the key area were studied on the basis of field interpretation of high-resolution satellite images (WorldView-2 with a resolution of $1.8 \mathrm{~m}$ ) using a multispectral image segmentation algorithm, based on computationally efficient hierarchical clustering algorithm HECA, and spectral-texture segmentation algorithm ESEG.

They are shown in the legend of the map for the key area in the eastern part of the EchkiDag mountain range and are based on taking into account the hierarchy of regional and local environmental factors.

The substantial part of the large-scale map in the eastern part of the Echki-Dag ridge at a visible scale is presented in two parts (in Figures 1 and 2) with a single legend. Two parts of the cartographic model represent ecological and geomorphological series of vegetation and combinations of xerophytic and mesoxerophytic plant communities within two phytochorias of the highest rank. The legend presents the regularities of vegetation formation associated with erosion-denudation processes on different substrates of the bedrocks.

Legend of the large-scale vegetation map of the eastern part of the Echki-Dag ridge.

Vegetation of the geomorphological belt of colluvial plumes (200-400 m).

1. Vegetation of colluvial trails and near-watershed slopes (combinations of associations of weakly petrophytic xerophytic steppes of associations Artemisio alpini-Festucetum callierii and Artemisio tauricii-Koelerietum cristatii).

2. The vegetation of the stall walls and drainage depressions of the erosion-landslide relief is a combination of the petrophytic series of associations Euphorbio petrophylli-Cotoneasteretum, Alysso obtusifolio-Seselietum dichotomii, Hedysaro taurici-Agropyretum ponticii.

3. Landslide vegetation - moderately petrophytic meso-xerophilous communities of CotinoPaliuretum shrubs.

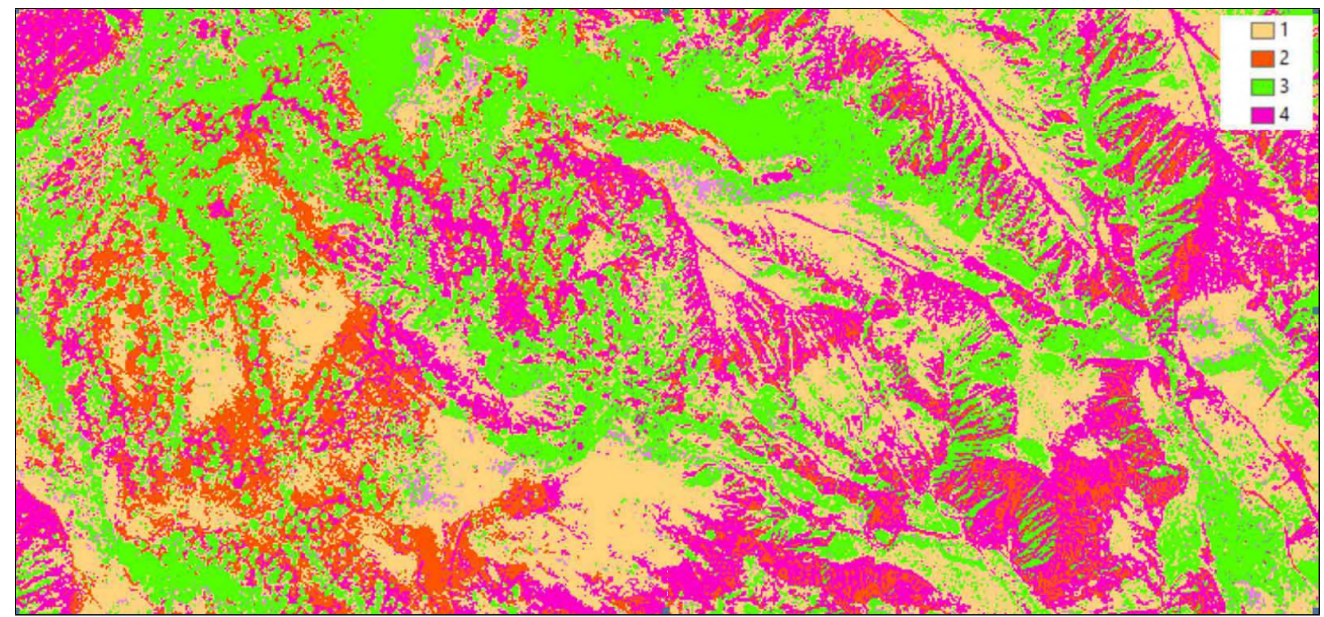

Figure 1: Fragment of a large-scale vegetation map of the eastern part of the Echki-Dag ridge (within the boundaries of the geomorphological belt of colluvial trails $(200-400 \mathrm{~m})$ created on the basis of high-resolution satellite image WorldView-2. The map legend is in the text. 


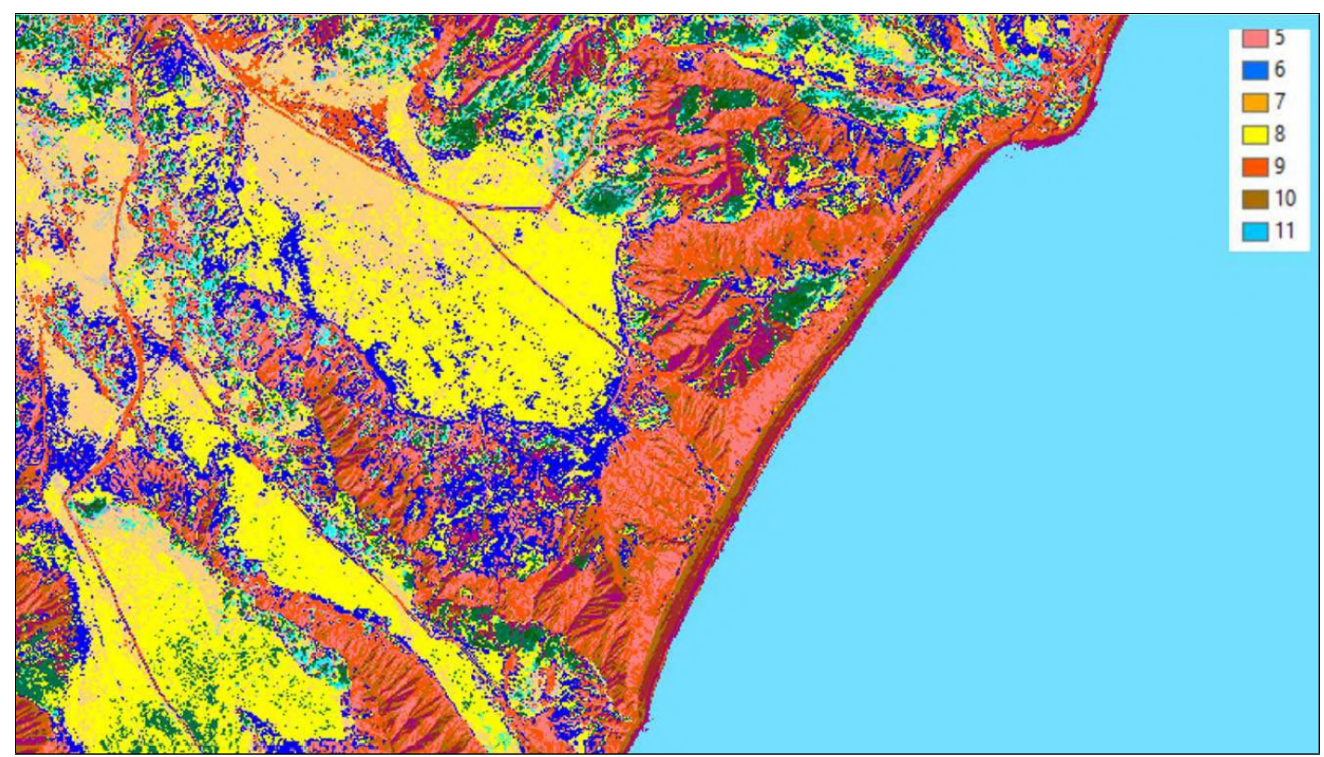

Figure 2: Fragment of a large-scale vegetation map of the eastern part of the Echki-Dag ridge (geomorphological belt of gully-gully relief with a wide development of fluvial terraces 0-100 (150) m), created on the basis of a high-resolution satellite image WorldView-2. The map legend is in the text.

4. The vegetation of the walls of the breakdown of ancient landslides - petrophytic xerophytic communities of the association Onosmo rigidi-Asphodeletum tauricii.

\section{Vegetation of the geomorphological belt of gully-ravine relief with wide development of fluvial terraces $(0-150 \mathrm{~m})$.}

5. Vegetation of eroded slopes of ravines from Maikop clays, fleeshes, sandstones and conglomerates (a combination of communities of the ecological xero-petrophytic series of associations Ceratoido papposae-Seselietum dichotomii, Astrodauco orientali-Ptilostemonietum, AstragaloTragacantietum).

6. The vegetation of the first and second proluvial terraces: weakly petrophytic xerophilous communities of Botriochloe-Paliurietum on well-developed soils.

7. The vegetation of the third, fourth, and fifth proluvial terraces: weakly petrophytic mesoxerophytic communities of the association Poterio-furinetum stoechadifolii.

8. Non-petrophytic vegetation of ancient slopes resting on high terraces: xerophytic steppes of the association Medicago romanici-Bromopsietum cappadocii.

9. The vegetation of the badlands of the southern slope is ultra-xerophytic petrophytic communities of the association Atrophaco-Capparidetum.

10. The vegetation of the shaded slopes of ravines and ravines: weakly petrophytic xeromesophilous communities of forests and woodlands of the association funipero-Quercetum pubescentis.

11. Sea area. 
The results of large-scale mapping of vegetation demonstrate the main regularities of the regional phytodiversity and also serve as the basis for assessing the resource potential of vegetation and the conservation value of communities. The associations shown on the map and their combinations are interpreted from the standpoint of resource and environmental significance according to data from thematic information systems "Rare and endangered plants of Crimea" and "Plant resources of Crimea". This made it possible to create a series of cartographic layers,

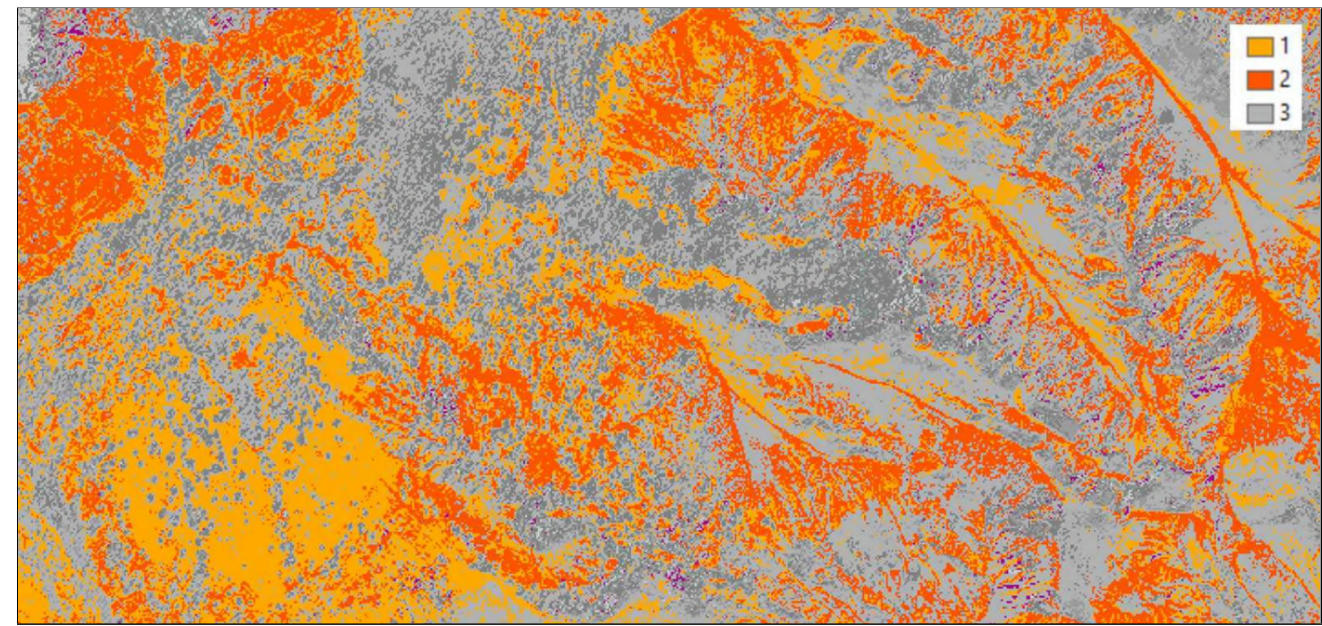

Figure 3: The cartographic model of the concentration of rare and endangered plant species demonstrates their highest number in the petrophytic series of associations - Euphorbio petrophylliCotoneasteretum, Alysso obtusifolio-Seselietum dichotomii and Hedysaro taurici-Agropyretum ponticii (1) as well as in the petrophytic xerophylous association Onosmo rigidi-Asphodeletum tauricii (2). Other vegetation communities -3 .

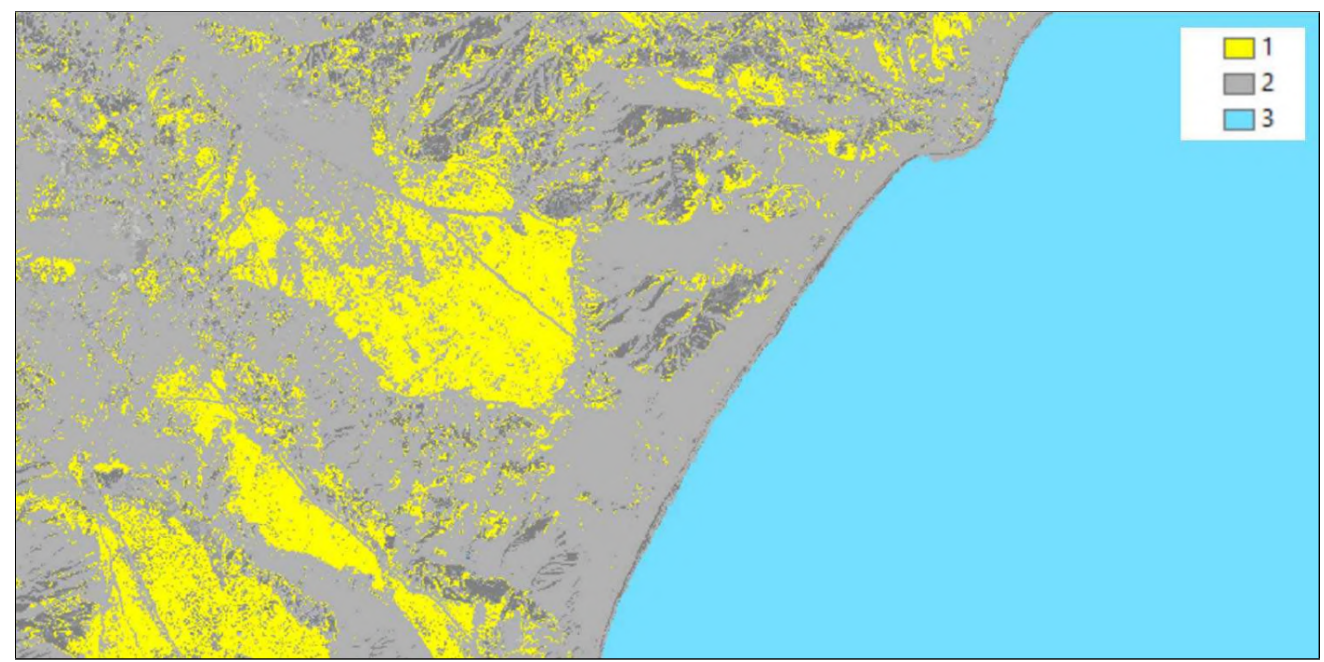

Figure 4: Cartographic model of the highest concentration of valuable medicinal plants according to the ratio of the "number of species - abundance-occurrence" values in the association Medicago romanici-Bromopsietum cappadocii (1). Other designations: 2 - other plant communities; 3 - sea area. 
in which not only the traditional quantitative indicators of important plant species, but also their ecological characteristics are reflected as accurately as possible to show the resource and nature conservation role of specific plant communities. This made it possible to create a series of cartographic layers that most accurately demonstrate the traditional quantitative indicators of important plant species, their ecological characteristics, the resource and nature conservation role of certain plant communities. The peculiarities of the distribution of groups of plant species (which are important in environmental and resource aspects) in the vegetation cover and in specific ecological and geomorphological conditions are shown on cartographic models (Figures 1 and 2). The cartographic model (Figure 3) shows the regularities of the concentration of rare and endangered plant species of Crimea in specific plant communities and their biotopes. These thematic models show that the largest number of these species is concentrated in the petrophytic series of plant communities of the associations Euphorbio petrophylli-Cotoneasteretum, Alysso obtusifolio-Seselietum dichotomii, Hedysaro taurici-Agropyretum ponticii, as well as in the petrophytic association Onosmo rigidi-Asphodeletum tauricii. At the same time, communities of the non-petrophytic association of xerophytic steppes Medicago romanici-Bromopsietum cappadocii (Figure 4) are of the greatest resource significance in terms of quantitative indicators (number of species, abundance, occurrence) of valuable medicinal plants.

\section{Conclusion}

As a result of the classification and analysis of the ecological composition of plant communities, ecological series and combinations determined by the factors of temperature, humidity and petrophyticity have been identified. These series demonstrate the regularities in the formation of xero-perophytic vegetation in the southeastern Crimea. For the first time for the Black Sea region, large-scale mapping of vegetation was carried out on the basis of high-resolution satellite images and the use of modern methods of processing remote sensing data. A series of maps of biotopes of rare and endangered plant species, resource significance of plant communities was created on the basis of detailed large scale cartographic models of vegetation. The obtained results are important for the conservation and rational use of vegetation, as well as for the development of a scientific and methodological approach to monitoring and predicting changes in the ecosystems and environment of the Crimea Republic. The implemented methodological approach allows large-scale mapping of vegetation using remote sensing data and modern information technologies.

\section{Acknowledgments}

The study was supported by budget theme of Nikita Botanical Gardens - National Scientific Center of the RAS (project No. 1009-2015-0018).

\section{References}

[1] Rubtsov N.I. Plant world // In: Rubtsov N.I., Makhaeva L.V., Shalyt M.S., Kotova I.N. The nature of the Crimea. Simferopol: Publishing house "Crimea", 1964. 123 p. 
[2] Didukh Ya.P. Vegetation cover of the Crimean mountains (structure, dynamics, evolution and protection). Kiev: Naukova Dumka, 1992. 256 p.

[3] Danilova I.V., Ryzhkova V.A., Korets M.A. Algorithm for automated mapping of the current state and dynamics of forests based on GIS // Vestnik NSU. Series: Information Technology. 2010. Vol. 8. Is. 4. P. $15-24$.

[4] Neshataev M.V., Neshataev V.Yu. Vegetation mapping for the cadastral assessment of Nature protected areas (on the example of the Lapland Nature Reserve) // Bulletin of the Samara Scientific Center of the RAS. 2012. Vol. 14. No. 1(6). P. 1630-1633.

[5] Kashirina E.S., Bondarev L.V. Mapping the vegetation of the landscape reserve of national importance "Cape Fiolent" and the zoological reserve of national importance "Bukhta Kazachya" (Big Sevastopol, Crimea) // Ecosystems, Their Optimization and Protection. 2013. Is. 8. P. 130-140.

[6] Ermakov N., Larionov A., Polyakova M., Pestunov I., Didukh Ya. Diversity and spatial structure of cryophytic steppe of the Minusinskaya basin in Southern Siberia (Russia) // Tuexenia. 2014. Vol. 34. P. 431-446.

[7] Polyakova M.A., Ermakov N.B. The study of steppe vegetation spatial structure in Khakassia using satellite images of different resolution // Ekosistemy. 2019. Is. 18. P. 3-13.

[8] Field geobotany. Methodical guide / E.M. Lavrenko (Ed.). Novosibirsk: Publishing House of the Academy of Sciences of the USSR, 1964. Vol. 3. $530 \mathrm{p}$.

[9] Hennekens S.M., Shaminée J.H.J. TURBOVEG, a comprehensive data base management system for vegetation data // Journal of Vegetation Science. 2001. Vol. 12. P. 589-591.

[10] Sochava V.B. Vegetation cover on thematic maps. Novosibirsk: Nauka, Siberian Branch, 1980. $190 \mathrm{p}$.

[11] Westhoff V., van der Maarel E. The Braun - Blanquet approach. // Handbook of Vegetation Science. 1973. Vol. 5. P. 617-726.

[12] Tichy L. JUICE, software for vegetation classification // Journal of Vegetation Science. 2002. Vol. 13. P. 451-453.

[13] Theurillat J.P., Willner W., Fernández-González F, Bültmann H, Čarni A, Gigante D, Mucina L, Weber H. International code of phytosociological nomenclature. 4th edition // Applied Vegetation Science. 2020. Vol. 24. No. 2. 62 p. DOI:10.1111/avsc.12491.

[14] Bel'gard A.L. Steppe forestry. Moscow: Lesnaya Promyshlennost, 1971. 336 p.

[15] Tsyganov D.N. Ecomorphes of the flora of coniferous-deciduous forests. Moscow: Nauka, 1976. $60 \mathrm{p}$.

[16] Gribova S.A., Isachenko T.I. Field geobotany. Methodical guide. Novosibirsk: Publishing House of the Academy of Sciences of the USSR, 1972. Vol. 4. P. 137-330.

[17] Pestunov I.A., Rylov S.A., Berikov V.B. Hierarchical clustering algorithms for segmentation of multispectral images // Optoelectronics, Instrumentation and Data Processing. 2015. Vol. 51. P. 329-338.

[18] Rylov S.A., Pestunov I.A. Fast hierarchical clustering of multispectral images and its implementation on NVIDIA GPU // Journal of Physics: Conference Series. 2018. Vol. 1096. P. 012039.

[19] Pestunov I.A., Rylov S.A. Spectral-textural segmentation algorithms for satellite images with high spatial resolution // Bulletin of Kemerovo State University. 2012. No. 4/2(52). P. 104-110. (In Russ.) 